of Wales, which he points out has afforded the people opportunities for the expression of their individuality in the fields of oratory, poetry and song. Through these our common British life has gained vastly from the spring of an ancient cultural tradition. By this tradition even the miners of South Wales have been preserved from the worst evils of industrialism. How to keep this contribution to our common life from submergence, Prof. Fleure concludes, is a problem worthy of much study.

\section{Aerial Ropeway in Central Sweden}

AN aerial ropeway of exceptional length is being built in Central Sweden for the purpose of conveying limestone from quarries to a new cement factory. From a description given in Engineering of October 18, we learn that the ropeway is 28 miles in length, and will be capable of transporting 700,000 tons of material per annum. The running, filling and emptying of the 550 skips used is carried out entirely automatically. The construction work is now well advanced; the supporting towers have been erected along the entire route, and the work of placing the cable in position has now begun. Several difficult problems have been successfully solved. One of these was the best way to convey the ropeway across two wide waterways. In one case this has necessitated the suspension of the ropeway at a height of 22 metres to enable ships to pass freely underneath. In addition to carrying the line across a lake, concrete towers, $147 \mathrm{ft} .7 \mathrm{in}$. in height, have had to be built in the water. It is anticipated that the installation will be completed by the end of the present year.

\section{Mental Hygiene of Old Age}

IN a recent paper (Mental Hygiene, 24, $734 ; 1940$ ) Dr. Nolan D. C. Lewis, director of the New York State Psychiatric Institute and Hospital, New York City, makes the following recommendations for avoiding or relieving the mental troubles of old age. In the first place, the senile individual should be used economically by arrangement of changes of work and frequent rest periods. The individual should be relieved so far as possible from worry, mental strain, anxiety and feelings of financial insecurity. With the gradually devitalizing processes in mind, special care should be taken to avoid physical discomforts, vitiated air, infections and over-eating. The senile patient should also be protected from injuries, as they may produce or increase a tendency to hypochondria. It is important to avoid any heavy burden on the sense organs through which exhaustion of the central nervous system may occur. The younger and more able associates of the senile individual should make allowances for the occasional lack of acuity in dealing with situations which require fine discrimination and tact. Tolerance and understanding should be used with the aged person who shows a marked egoism together with uneasiness, restlessness and a tendency to harp on his difficulties.

\section{Folk-lore of the U.S.S.R.}

THE Academy of Sciences of the U.S.S.R. is to issue a new work entitled "Soviet Folk-lore", into the compilation of which has gone much effort on the part of many expeditions to different parts of the Soviet Union. An expedition sent out to the Stalin. grad Province by the University of Leningrad has collected much interesting material relating to the folk-lore of the Don Cossacks. In the villages and farmsteads of that province the expedition recorded 110 folk-tales, 550 Cossack songs, as well as numerous proverbs and legends. Among the songs are some about Stepan Razin, Yermak, Peter the Great and the War of 1812. This expedition has also collected interesting material relating to the new Soviet folklore of the Don Cossacks. Records were made of songs and tales on the subjects of Stalin, Voroshilov, Budenny, the Civil War and the collective farm.

\section{Adams Prize: Subject for I94I -42}

The Adams Prize, which is open to the competition of all persons, including women, who have at any time been admitted to a degree in the University of Cambridge, is awarded for an essay, the subject proposed for the period 1941-42 being "The theory of the elementary physical particles and their interactions". The essay may contain a discussion of the properties of some or all of the elementary physical particles and of their associated fields; the theory of cosmic rays and the structure of nuclei come under the scope of the subject. The value of the Prize is about $£ 288$, but may be increased, when it seems desirable to the adjudicators, on occasions when the prize is divided. Provision is also made for the award of extra Adams Prizes in suitable cases. The essays must be sent to the Registrary of the University on or before December 31, 1942 .

\section{Comet Okabayasi}

HaRvard College Observatory Card 539 reports the discovery of a comet of magnitude 11 on October 4 by Okabayasi. Card 540 gives the following elements and orbit computed by Miss Scott at Berkeley :

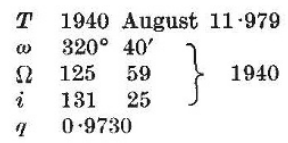

\section{Announcements}

Mr. Francis Druce has resigned the honorary treasurership of the Linnean Society after serving for nearly ten years. On November 7 the Society elected as his successor Major F. C. Stern.

The Rockefeller Foundation, the Carnegie Corporation and other United States bodies have guaranteed $£ 125,000$ to take to America a hundred leading scholars who have fled from Germany.

Errata. In the article on "Early Explorers of Southern South America from the United States" in NATURE of August 17, p. 238, line 5, for "Stongington" read "Stonington", and line 8 for "Jerimiah $\mathrm{N}$. Reynolds" read "Jeremiah N. Reynolds". 